\title{
Self-Care and Empowerment in Postpartum: Social Representations of Puerperae
}

Hilana Dayana Dodou1, Dafne Paiva Rodrigues², Ana Carolina Maria Araújo Chagas Costa Lima1, Mônica Oliveira Batista Oriá', Régia Christina Moura Barbosa Castro1, Nayara Souza de Mesquita², Ana Beatriz Azevedo Queiroz ${ }^{3}$

\section{Abstract}

Introduction: The puerperal period occurs when starting the restoration of the woman's body after the situation of pregnancy phase, with a transition period in which mothers need to practice self-care for their own benefit, welfare, and health. The care of health professionals in this period should involve guidance to postpartum women, so they understand the importance of taking care of themselves and become able to perform self-care. The aim of this study was to investigate the social representations of puerperal women about self-care and their relationship to the empowerment postpartum.

Method: This is a descriptive and a qualitative study conducted with 19 mothers from five family health centers. We used the Theory of Social Representations as theoretical and lexical analysis method, using ALCESTE software - version 2012.

Results and Discussion: Self-care of mothers is surrounded by influences, beliefs and practices, which are derived from the experiences of other women in the family and social environment. The contents of the social representations of puerperal women about self-care announce that it is mainly related to the biological dimension of women, valuing the care of the body.

Conclusion: Nursing must provide the necessary support for the postpartum women, so they feel able to perform self-care and encourage their own empowerment, developing their autonomy, knowledge and skills so they can have greater control over the factors that affect their health and are trained to the practice of self-care.
1 Federal University of Ceara, Fortaleza, Ceara, Brazil.

2 State University of Ceara, Fortaleza, Ceara, Brazil.

3 Federal University of Rio de Janeiro, Rio de Janeiro, Brazil.

\section{Contact information:}

Hilana Dayana Dodou.

Federal University of Ceara.

Address: Rua Alexandre Baraúna, 1115, Rodolfo Teófilo. Fortaleza, Ceará, Brazil.

” hilanadayana@yahoo.com.br
Keywords
Women's Health; Postpartum
Period; Self-care; Health
Promotion; Nursing. 


\section{Introduction}

The puerperium is a critical period of transition in the lives of recent mothers, marked by several physiological, emotional and psychosocial changes that start soon after birth and can prolong until the end of the first year of life of the child, being a singular moment for every woman, once it is filled with new situations and needs.

Given this, nursing care must involve guidance to who has recently given birth, so that they understand the importance of taking care of them and become able to perform self-care in this new phase. At this point, it is important that the nurse clarify doubts and guide women in self-care actions that can and must be exercised during the puerperium.

Self-care is the practice of activities that the individual performs for its own benefit, well-being, health and quality of life. This is a regulatory function, a deliberate action to provide or ensure the provision of the information necessary to continue its life, growth, development and maintenance of human health [1].

In this context, the nursing professional has a relevant role in who has recently given birth assistance, performing the function of educator, promoting health and contributing to quality of life [2].

The postpartum period assistance must provide an interactive and effective care, consistent with the biopsychosocial needs of women. In addition, for the woman feel confident and motivated for the practice of self-care, it is necessary that health professionals involved in assistance to encourage women's empowerment that has recently given birth in the postpartum period [3].

Empowerment is a fundamental concept for health promotion present in the Ottawa Charter for health promotion in 1986, understood as the process of enabling individuals and communities to take greater control over the personal, socioeconomic and environmental factors that affect health. [4] It is connected also with fairness, the actual conditions that people have to their advantage for healthy living conditions communication and social participation [5].

Thus, empowerment is a process of mobilization and practices aimed at boosting individuals and collectivities in increasing control over the determinants of health, and the development of their autonomy by means of social participation, with a view to improving quality of life [6].

Nursing plays an essential role in empowering the individual to make decisions about his health and contribute to his empowerment. In this sense, the nurse should encourage the autonomy of who has recently given birth to perform its self-care, valuing respect to its cultural peculiarities and the care of its individual needs and community for a healthy life.

Nursing professionals must act in accordance with the health promotion approach, contributing to the development of skills of recent mothers, in order to help them in the growing control over their life and health. The personal and social development of the subject by means of information, health education and strengthening of vital skills encourages women to exercise greater control over their own health, contributing to their empowerment [7-8].

Given this, nursing should act according to the actual needs of who has recently given birth, developing a healthcare plan that allows the woman a good adaptation to this stage, by actually Instrumenting-not only to provide child care, but mainly to perform her self-care in order to obtain the knowledge and security needed to take care of herself during this period.

Nevertheless, it still can see the lack of interest and attention of the health team to the needs of women in puerperal period, evidenced by the lack of teachings about the care that these should be right with them, focusing only on guidelines for breastfeeding and newborn care. Health professionals have worked under a vision biologicist and fragmented, neglecting many times educational activities both in individual and collective scope $[9,10]$. 
From these reflections, we decided to work the object of study proposed in the light of the theory of social representations, believing that this will give subsidies to understand referential self-care in the postpartum period, from its meanings, beliefs, and pre-existing knowledge of recent mothers about this period.

The Theory of Social Representations (TRS) proposes that people are social subjects, and as such, develop representations, they formulate their own knowledge about relevant elements in their lives, from what experience, than share with other subjects and the influence that scientific knowledge and the media exert on them [11].

Before that, there is as its aim to investigate the social representations of recent mothers about selfcare and their relationship with the postpartum empowerment.

The relevance of this research lies in the potential of incorporating a new nursing practice directed at women in puerperal period, focusing on the empowerment of recent mothers to take care of themselves, highlighting their meanings, experiences, and knowledge about this moment.

\section{Method}

This is a descriptive study with a qualitative approach, using a procedural approach to the Theory of Social Representations (TRS) [11]. The setting of the study were five family health Centers (CSFs) of Regional Executive Secretariat (BE) IV, of the municipality of Fortaleza/Ceara.

The collection of the information took place in the period from June to September 2014 with 19 users randomly chosen, which met the following inclusion criteria: be registered in one of the surveyed units are in the phase of late or remote, puerperium with age equal to or older than 18 years old. There were excluded women who left the area covered by the CSF of BE IV (for change of address) in the collection of information, and the recent mothers with mental disorders or cognitive deficits, identi- fied in the initial contact with the participants. The theoretical data saturation was used as criterion to define the set of study participants [12].

The approach with the participants was established through visits made by the researcher to five CSFs. The relationship with the recent mothers has occurred by presentation of the researcher, with explanation of the survey, and their goals. In addition, these women were informed that the research would occur in their home environment. After clarification of the recent mothers, was asked to consent to participation in research and scheduled a visit to the researcher to their home, according to the convenience of them.

There were used in gathering information the semi-structured interview and an instrument to profile and demographic of the birth. The script of the interview intended to explore the meanings assigned to self-care in the postpartum period.

The interview was conducted at home, once for each participant, through a visit made by the researcher, and had an average duration of 10 minutes. It was conducted only by the lead researcher, who was then a graduate student, and had experience in research in the area of women's health.

In some situations, family members were present at the time of research, but it was clear to respect the privacy of who has recently given birth and not to interrupt the interview. The notes pertinent to the research were carried out after the interview. The dialogues were recorded, transcribed in full and prepared the database, which was organized from the lexical analysis method, and rendered in software version 2012 Alcestis. The transcript was not submitted to the participants of the study.

The ALCESTE software employs a hierarchical classification analysis (CHD) and allows a lexical analysis of textual material, offering contexts (lexical classes) that are characterized by their vocabulary and text segments that share this vocabulary. [13].

The corpus of analysis is formed by the initial context units (UCls), from which the program will perform the initial fragmentation and that correspond 
to each interview. After the program to recognize the signs of UCls, this divides the material in context elementary units (UCEs), units with less sense fragment, scaled by the computer program according to the corpus size [13].

The program provides, so, the number of classes resulting from the analysis, as well as the reduced forms, semantic context and the UCEs features of each class. In possession of this material, the authors set the content present in the same, naming each class from all the information provided by the program.

In addition, the software provides the Phi coefficient, a coefficient that measures the Association connection between a Word and its appearance. The higher the Phi, most relevant is the word for the construction of the class. The testimony of the participants is identified according to the number of the $\mathrm{UCl}$ which were part, i.e. according to the number of their interview, and UCE.

From the information processing in ALCESTE, the UCEs were classified in classes, writing the results of a major study. For the purposes of this study, there were explored and discussed the contents present in the class "the care of themselves in the puerperium", since it is in this that focus the lexicons that exploit the object clipped to the discussion of this article. The interpretation and analysis of classes based on the perspective of the Theory of Social Representations. In addition, we used the COREQ Protocol (Consolidated Reporting Criteria for Qualitative Research) with the purpose of enabling the improvement of the presentation of the results of this research.

The search occurred only after approval by the Research Ethics Committee of the State University of Ceara, No 630.912, from April 9 $9^{\text {th }}, 2014$. All ethical and legal principles have been complied with, in accordance with resolution $N^{\circ} 466 / 12$, which regulates research with human beings [14].

\section{Results and Discussion}

Regarding the socio-demographic profile of participants, chosen and could see that it was composed mostly by women multiparous (10), between 18 and 25 years of age (11), married (8), with full high school (13) and that not exercising gainful employment (11).

The class was comprised of 84 UCE and 46 analyzable words. In terms of aggregation of UCE, had great statistical significance, representing 32\% of total UCE of all classes. The program considered for all classes only words with Phi 0.16 or greater as more representative, that is, only these words are considered relevant to the class approached.

The words more illustrative of this class were: guard (Phi $=0.40$ ), have (Phi $=0.30$ ), home (Phi $=$ 0.29), break (Phi $=0.29$ ), point (Phi $=0.27$ ), care (Phi $=0.26)$, stress $(0.26)$, sweep (Phi $=0.24)$, infect (Phi $=0.24)$, rode $(P h i=0.23)$, hygiene $(P h i=0.23)$, cut $(0.22)$, surgery (Phi $=0.21)$, important $(P h i=0.22)$, dressing (Phi $=0.21)$, good (0.20), head (Phi $=0.20)$, flamed $(P h i=0.19)$, none $(P h i=0.19)$ lying $(P h i=$ 0.18), plant (Phi $=0.16)$, part (Phi $=0.16)$, three (Phi $=0.16$ ).

These words express how postpartum women were and what precautions they should take. The class represents the lines of recent mothers in relation to care that they had with you during the puerperium, and the care that they should have had, since despite having knowledge about selfcare in the puerperium, the speeches show that not all practice that care.

One can see through the most representative words and UCE, the social representations of women about self-care in the puerperium are related mainly to watch the body, to ensure the recovery of the woman in this period of life and avoid possible complications in the puerperium. In General, the representations of the self-care involved four dimensions: home, watch the surgery, careful with food and hygiene.

In the consensual universe that have recently given birth the postpartum period is perceived as a time 
when it is essential to have great care, attention and rest in order to recover and avoid possible complications. Some expressions such as don't make effort, home, quiet and not catch weight were considered essential for the restoration of women's health:

...the guard to me I don't even know what to say, is not good, why do they have to be very carefully, all the attention...

uce N 230 uci N 11.

...didn't have one I had peace of mind. And even my older girl was my sister-in-law who took care of me, so I had the guard. Important care is to have the rest, not to make any effort, the peace that the person has the right to health of people... uce $\mathrm{N} 68$ uci $\mathrm{N} 4$

...lying the way more comfortable to me. Home, keep at rest, as I spent I don't know how many days in the hospital, I kept having this home at home, eating well and only...

uce N 51 uci N 6.

I think the guard's home; you really need attention, especially if caesarean, woman I think careful in everything, to have home, help, to have attention.

uce N 236 uci N 12.

The only thing they told me is that when I got home I had minimal home, at least until you get the stitches because it could break and ignite and was going to be worse for me.

uce N 261 uci N 13

The guard to me is a very special moment for the woman, because I think she should have, because the future will see the consequences, good or bad. Then I had my husband's attention, which was very important. In my house people were with me, were very patient, and had a good power supply

uce N 349 uci N 19
The puerperal anchor the guard in the dimension of care and caution, since this period as a time symbolize of dangers and weaknesses, it is necessary to follow certain restrictions to prevent bad consequences.

The behavior of women in the postpartum is supported in what they know, involving so care aimed at protecting them. Among these is the absolute home care for long periods, in which the woman must stay in bed for weeks, avoiding physical effort, catch weight and perform household activities [15].

In the puerperium, the care and self-care received are wrapped by influences, beliefs and practices, which are passed from generation to generation. These influences have origin in accounts of experiences and in the tradition of women in his family and his social environment. This knowledge that is shared socially has a real value to those who have recently given birth, causing them to feel confident in using it in the conduct of their care [11].

The postpartum period is a phase in which the woman is very sensitive and vulnerable to complications, so if necessary care and attention on the part of the health care team so that they can experience this moment of quiet way, healthy and without complications.

In statements, the women are experienced stage as "guard", turning the concept of that moment in a figurative core that is part of their reality. This name represents the meaning that this stage has for the recent mothers, as a period in which they must protect, care for and obey certain rules and restrictions culturally learned, in order to avoid relapse, what constitutes complications arising from the undue self-care $[15,11]$.

During the puerperium, the woman finds herself surrounded by a series of changes imposed by pregnancy and birth, experiencing profound changes in the social, psychological and physical dimensions. Common sense, this step of the female life is a period of unstable and potentialities, which demands attention and care by all around [16]. 
Realize that this period is marked by knowledge accepted socially as facilitators of a good postpartum recovery. Such knowledge is produced at the heart of relationships and conversations with these women; they interpret in its realities what has meaning for them. This phase represents a period of risks and potential dangers for women, so are valued in their speeches and their social care practices that can avoid these dangers and appreciate for their health.

The social representation is that particular knowledge mode whose function in the development of behaviors and communication between individuals. The social representations of the recent mothers about self-care are symbolic/practical/dynamic sets whose status is not represented by the reproduction or reaction to outside stimuli, but by the use and selection of information from the current repertoire in society, intended for interpretation and elaboration of real [11].

In this context, health education is one of the activities that can be used by a nurse to the encouragement to women empowerment in the postpartum period, and the opportunity to develop the autonomy of who has recently given birth, and the skills necessary for the practice of self-care.

It is therefore important reflection of that empowerment is an educational process that helps people develop knowledge, skills, and attitudes necessary to assume responsibility with the conscious decisions about their health. [5] Recent mothers more informed, involved and responsible interact more effectively with health professionals, and are more qualified to perform and take control of their postpartum care.

In the educational process carried out by the nurse, it is important that who has recently given birth to understand the knowledge that is being shared. For this, it is essential that the nurse recognizes the reality of women, along with careful practices used for this and their family in the puerperium and thus perform the teaching-learning process effectively, through the clarification of previous knowledge and experience of these guys, to make them feel truly supported [17].

In these circumstances, health education is set up as an eye shadow strategy nursing care in postpartum period and should occur through educational practice articulated the expectations, demands and knowledge of recent mothers, characterized by properly contextualized care guidelines, based on a relationship of trust between a nurse and who has recently given birth, because only in this way can have an impact on healthy women's adaptation to this stage and help promote their health.

The accession of women to self-care is intrinsically linked to this relationship that is established with the professional, and should be based on trust, with due regard to the concerns and culture, listening to their needs, to establish link and autonomy, accountability (empowerment), and construction plans that promote health care [5].

Careful with the surgical site was also highlighted by women undergoing Cesarean delivery. You can see through the lines, that the recent mothers have knowledge of possible complications arising from a C-section, so hygiene at the surgical site and the home are reported as care that can prevent infection and disruption of the points:

you have to have a lot of hygiene, because something is cesarean section, you have to have a lot of hygiene, because otherwise infects and also has to be careful themselves. If cesarean section and with the stitches you have to get if you have flamed have to do dressing to heal, be careful. uce $\mathrm{N} 338$ uci N 18.

rest, be careful with stitches, not ignite until today my stitches hurt too much, I don't know what happens, very inflamed also. No, I never went to the hospital, they who cared there because I spent one month and 15 days in the hospital. They made the dressings, but he is very inflamed my surgery, it hurts too much, much too much. uce $\mathrm{N} 14$ uci N 2. 
...she didn't even get up, her surgery started to fester. Her surgery started to drop, infected. She made no effort. As for me, when I had it, with four days it seemed that I had, was, did everything. I guess I just really stress, not having a lot of stress to not break also...

uce N 108 uci N 6

In their speeches the women also report the importance of avoiding domestic activities, since they require physical exertion, and have a balanced diet in order to avoid "breaking points" and "ignite" surgery, emphasizing again the importance attributed to post-partum surgery.

...careful with everything, don't pick up weight, not sweeping, not ironing cloth, not break stitches, be careful with the surgery, because it is important for health. It's been great so far, I bathe, wash stitches, as three in 3 hours, do everything not to inflame the surgery.

uce N 231 uci N 11

...the food too, I always had my regular feeding, good, careful in cleaning too, always they talk to have hygiene, not to infect the points and not have anything severe.

uce $\mathrm{N} 90$ uci $\mathrm{N} 5$.

In the consensual universe of recent mothers, postpartum is represented as a worrisome and dangerous, because of this, they point to his speeches some practices as necessary to prevent complications. The home is seen as a fundamental practice in the postpartum period, and family members encourage like healthy recovery facilitator, assisting in household chores. According to know popular refrain of these tasks helps in the recovery of the uterus, as well as prevents bleeding [15].

The power care is also a concern very evident in the speeches of those women, emphasizing the importance of regular and balanced nutrition for women's health in the puerperium and to prevent inflammation. Food is a subject much discussed with women from pregnancy, when they receive guidance from their families and professionals about the foods that should be restricted and that bring benefits for women [18].

The local surgery care, hygiene and nutrition in the postpartum period is a form of private knowledge of recent mothers, which was socially prepared and shared, having a practical goal, to guide the conduct of women during this period of life, contributing to the construction of a common reality to their social set. These social representations about self-care in puerperium can be designated as the knowledge of the common sense of women, or even know naïve, natural, a form of knowledge, among others, of scientific knowledge, and with meaning and relevance to the social group in which permeates [11].

One of the functions of the social representations is to contribute with the processes of formation of conduits and communications guidelines of social groups, so they favor the placement of recent mothers in front of the object represented, the puerperium, guiding their attitudes, behaviors and practices. Thus, before the social representation of the puerperium as a period of fragility and danger, the women suggest actions, attitudes and practices of care to minimize or even avoid the danger to which they are exposed [11].

This class introduced association for multiparous women (Phi $=0.24$ ), who studied only up to the elementary school (Phi $=0.23$ ). This means that even though they have a low level of education, these women present knowledge about self-care in the postpartum period, due to their previous experiences of pregnancy and to the information, knowledge and practices that are socially shared by people that make up their social and family group.

Despite recent mothers having knowledge about appropriate self-care practices in puerperium, they need encouragement to materialize. For this, the nurse should articulate in their care an educational work during the gravid-puerperal cycle, in order to 
stimulate self-care and enabling wife self-sufficiency postpartum [19].

In the statement below, who has recently given birth reports help you received from your neighbor about the surgery care, that portrays the woman recognizes and values the knowledge of those who are part of your social group, relying on this known to guide the care of them:

I feel headache, I feel back pain, foot pain in the belly. I took care of the scar, I don't, the neighbor who cared, she cleaned with mastic, cleaned spotless, then ready scarred.

uce $\mathrm{N} 70$ uci $\mathrm{N} 4$.

The contributions of the use of the mastic for wound healing are anchored in popular knowledge (cultural), which has been handed down by people between the generations, causing it to be continuously used in the postpartum period. This is due to the fact that people formulate their own knowledge from what experience, than share with other subjects, and the influence of the media and of scientific knowledge. This knowledge that emerges and spreads in the social environment is what has real meaning to people, guiding their practices and actions toward a certain subject that has value to them [11].

The knowledge about the use of mastic arose from the ancient civilizations that were seeking in nature the remedies for curing diseases. Mastic is one of plant remedies gynecological use more frequent and older ones used in folk medicine, mainly in northeastern Brazil. This plant has great reputation as anti-inflammatory and healing, and can be used in the treatment of infections and inflammations in general, in the post-partum sequelae and treatment of the skin and mouth [20].

In this context, the appointment of puerperal nursing presents itself as an important space for the woman to take her tasks, learn to care for and be cared for, being a rich opportunity for the teaching and learning of a woman who has recently given birth. Including a space to be discussed beliefs and myths and guide the woman to better conduct. During this time, the nurse, as an educator in health, it is co-responsible for building the autonomy of who has recently given birth, and may contribute to these make their choices, take the promotion of their own health and become empowered [21].

Despite having knowledge of care which are indispensable during the puerperium, some women report that they couldn't get the care necessary for their recovery, since they had to go back to your daily routine, performing household activities, and playing the maternal role, through newborn care:

My guard I think it was just a day, because I did everything on the second day I was, sometimes I was sleeping at home.

uce N 109 uci N 6.

I'm a lying part, then there will walk, because you don't have go through to lie, not only have to take care of him, have things to do, like it or not has to help.

uce $n^{\circ} 313$ uci $n^{\circ} 17$.

The experience of motherhood implies new responsibilities to his wife as the son, which demand a lot of time, effort and attention on the part of the mother, which added to the other attributions of women make the same can't have the care necessary for their recovery in the post-partum period. Despite acknowledging the important care in puerperal period, some women are unable to exercise it, because the context in which they live does not allow, because the other requirement that the same demands should meet at this time with their son.

Speaking of the recent mothers below demonstrates that their postpartum was marked by lack of sleep and the stress, associating the wear and the suffering caused by stressors stimuli to physical complaints such as headaches, pain in the surgical site and dizziness: 
...the Guard I didn't, because I didn't have a home, I had no peace of mind, I had a lot of stress. After I had a lot of stress headaches, dizziness, and pain in my operation that I did. Guard is to have home, having food at the right time, be left alone which is something I haven't had...

uce $\mathrm{N} 85$ uci $\mathrm{N} 4$.

...it was just a face, because I had to be careful not to break the guard and everything, I felt some headaches, but was due to the stress, but the period after normal guard, just to be careful even with the guard...

uce N 280 uci N 14.

The puerperium is a period marked by changes that can lead to discomfort and cause stress, physical and emotional wear and tear to the woman. When who has recently given birth cannot be taken and the necessary rest, their health and well-being are compromised, and she suffers from physical complaints.

The birth of a baby has been associated with situations of stress for some women, given the changes in daily routines that have occurred since the gestation period, at the time of birth and in puerperium phase [22].

Careful with body image and with the mind was highlighted by a who has recently given birth, highlighting the importance of the care of themselves during the postpartum for self-esteem and well-being of women, as well as to avoid possible psychoactive, disorders like postpartum depression:

Took care of my beauty I did, took care of my hygiene, showered, if ever shaved. Had home, slept when she was sleeping. I was reading, I was reading to distract, because sometimes the person is confined and thinking something else, postpartum depression, it then I think it's very important to help.

uce N 304 uci N 16
Among all the stages of a woman's life, the postpartum is the period of greatest vulnerability for the emergence of psychiatric disorders, including postpartum depression is one of the most recurrent disorders. This is due to the fact that the transition to motherhood is marked not only by biological changes, but also psychological and social change, which if not well conducted can cause distress and result in movement disorders [22].

In the puerperium there is no need of social reorganization and adaptation to a new role, the woman has a sudden increase of responsibility for care provider become a helpless person, and can suffer sleep deprivation, social isolation and stress. In addition, restructuring of sexuality, body image and identity.

Because of this, it is necessary that the care at this time does not involve only the biological dimension, but that it also contemplates the psychological, emotional and social dimension of the woman, being valued care practices that allow the woman to experience this phase in its fullness, so safe and happy.

Thus, it was noticed in this study that self-care is covered by influences, beliefs and practices, which originate in the experiences of other women in the family and in their social environment. It is necessary that nursing provides support and attention to the needs of who has recently given birth, enabling it to perform their self-care in order to obtain the knowledge and security needed to be empowered to take care of themselves during this period.

\section{Conclusions}

The contents of the social representations of recent mothers about self-care announce it is related mostly to the biological dimension of women, valuing the watch body to ensure the recovery and women's health in this period of life.

Although women have knowledge about the care they should have in the postpartum period, 
sometimes they can't drive it due to difficulties they experience during this period. The performance of the maternal role and the other demands of care spend time and effort on the part of women, committing their self-care.

Therefore, nursing should provide the necessary support so that the who has recently given birth to feel able to perform self-care and encourage their empowerment, seeking to develop their autonomy, knowledge and skills so that they can have more control over the factors that interfere with their health and are qualified to practice self-care.

It is necessary that a nursing educational work articulated the expectations and demands of women throughout the gravid-puerperal cycle in order to stimulate the empowerment of recent mothers, and contribute to the promotion of health.

In addition, health professionals need to consider the symbolic universe of recent mothers about postpartum care, enhance social knowledge and their experiences, incorporate their relational environment, and meet the social context where they are, so that their actions are of effective support, helping women to experience this period more secure, confident and enjoyable.

As limitations of this study, show the number of participants, the restriction to the CSF of a single regional $(\mathrm{BE})$ from the State capital of Ceara, and not have involved health professionals. We must develop new studies that investigate how these nurses are preparing the recent mothers to carry out their self-care, and how you can encourage the empowerment of these women.

\section{References}

1. Orem DE, Taylor SG, Renpenning KML. Nursing: Concepts of practice. $6^{\circ} \mathrm{ed}$. Universidade de Michigan: Mosby; 2001.

2. Moura MAV, Costa GRM, Teixeira CS. Momentos de verdade da assistência de enfermagem à puérpera: um enfoque na qualidade. Rev. enferm. UERJ. 2010 Jul-Set; 18(3): 429-34. Disponível em: http://www.facenf.uerj.br/v18n3/v18n3a16.pdf
3. Barreto $B C R$, Moreira MA. Motherhood experience on puerperium and its interference in self-care practice. Arq Ciênc Saúde. 2014 Jan-Mar; 21(1):29-35. Disponível em: http:// repositorio-racs.famerp.br/racs ol/vol-21-1/ID 562 21(1) (Jan Mar 2014).pdf

4. Organização Panamericana de Saúde (OPAS). Carta de Otawa. Primeira conferência Internacional sobre promoção de saúde. OPAS; 1986. [site na Internet]. [acesso 2015 nov 16]. Disponível em: http:// www.opas.org.br/promocao/uploadArq/Ottawa.pdf

5. Taddeo PS, Gomes KWL, Caprara A, Gomes AMA, Oliveira GC, Moreira TMM. Acesso, prática educativa e empoderamento de pacientes com doenças crônicas. Ciênc. saúde coletiva. 2012 Nov; 17(11):2923-30. DOI: http://dx.doi.org/10.1590/S1413$\underline{81232012001100009}$

6. Heidemann ITSB, Wosny AM, Boehs AE. Promoção da saúde de mães adolescentes: investigação temática de Freire na Saúde da Família. Rev Rene. 2011 jul-set; 12(3):582-8. Disponível em: http://www.revistarene.ufc.br/vol12n3 pdf/a19v12n3.pdf

7. Ministério da Saúde (BR), Secretaria de Políticas de Saúde. Projeto Promoção da Saúde. As cartas da Promoção da Saúde. Brasília: MS; 2002. Disponível em: http://bvsms.saude.gov.br/ bvs/publicacoes/cartas promocao.pdf

8. Monteiro MAA, Oliveira SHS, Pinheiro AKB, Ximenes LB, Barroso MGT. Promoção da saúde de puérperas: conhecimento e práticas de enfermeiras. Rev Rene. 2012; 13(2):280-90. Disponível em: http://www.revistarene.ufc.br/revista/index.php/ revista/article/view/211/pdf

9. Rodrigues DP, Dodou HD, Lago PN, Mesquita NS, Melo LPT, Souza ASS. Care for both mother and child immediately after childbirth: a descriptive study. Online Braz J Nursing. 2014; 13(2): 227-38. DOI: http://dx.doi.org/10.5935/1676-4285.20144231

10. Oliveira JFB, Quirino GS, Rodrigues DP. Percepção das puérperas quanto aos cuidados prestados pela equipe de saúde no puerpério. Rev Rene. 2012; 12(1):74-84. Disponível em: http:// www.revistarene.ufc.br/revista/index.php/revista/article/ view/19/15

11. Moscovici S. Representações sociais: investigações em psicologia social. 10. ed. Petrópolis: Vozes; 2013.

12. Fontanella, BJB, Lucheri, BM, Saidel, MGB, Ricas, J, Turato, ER. Amostragens em pesquisas qualitativas: proposta de procedimentos para constatar saturação teórica. Cad. Saúde Pública. 2011;27(2):389-394.

13. Camargo BV. Alceste: um programa informático de análise quantitativa de dados textuais. In: Moreira ASP, et al., organizador. Perspectivas teórico-metodológicas em representações sociais. João Pessoa (PB): Editora Universitária UFPB; 2005. p.511-39.

14. Ministério da Saúde (BR), Conselho Nacional de Saúde. Resolução n 466/12 sobre pesquisa envolvendo seres humanos. Brasília: MS; 2012

15. Acosta DF, Gomes VLO, Kerber NPC, Costa CFS. Influências, crenças e práticas no autocuidado das puérperas. Rev. esc. enferm. USP. 2012 Dec; 46(6):1327-33. 
16. Strapasson MR, Nedel MNB. Puerpério imediato: desvendando o significado da maternidade. Rev Gaúcha Enferm. 2010; 31(3):521-8.

17. Bernardi MC, Carraro TE, Sebold LF. Visita domiciliária puerperal como estratégia de cuidado de enfermagem na atenção básica: revisão integrativa. Rev Rene. 2011; 12(esp):1070-80.

18. Marques ES et al. Representações Sociais sobre a alimentação da nutriz. Ciência e Saúde Coletiva. 2011; 16(10):4267-74.

19. Costa NS, Soares MBO, Melo MM, Parreira BDM, Silva SR. Self-care practice and nursing care demands by puerperal women. REAS [Internet]. 2013; 2(1):75-88. [acesso 2015 out 15]. Disponível em: http://www.uftm.edu.br/revistaeletronica/index. php/enfer/article/view/378/394

20. Machado AC, Oliveira RC. Medicamentos Fitoterápicos na odontologia: evidências e perspectivas sobre o uso da aroeirado-sertão (Myracrodruon urundeuva Allemão). Rev. bras. plantas med. 2014 Jun; 16(2):283-9.

21. Ribeiro DHF, Lunardi VL, Gomes GC, Xavier DM, Chagas MCS. Experiences of woman's care: the report of puerperal women. Rev enferm UFPE. 2014 Abr; 8(4):820-6.

22. Cantilino A, Zambaldi CF, Sougey EB, Rennó J. Transtornos psiquiátricos no pós-parto. Rev Psiq Clín. 2010; 37(6):278-84.

Publish in International Archives of Medicine

International Archives of Medicine is an open access journal publishing articles encompassing all aspects of medical science and clinical practice. IAM is considered a megajournal with independent sections on all areas of medicine. IAM is a really international journal with authors and board members from all around the world. The journal is widely indexed and classified Q1 in category Medicine. 